\title{
Monocyte Subsets: Phenotypes and Function in Tuberculosis Infection
}

\author{
Pavithra Sampath', Kadar Moideen², Uma Devi Ranganathan' \\ and Ramalingam Bethunaickan ${ }^{1 *}$
}

${ }^{1}$ Department of Immunology, National Institute for Research in Tuberculosis, Chennai, India, ${ }^{2}$ International Center of Excellence in Research, National Institute for Research in Tuberculosis, National Institutes for Health, Chennai, India

Monocytes are critical defense components that play an important role in the primary innate immune response. The heterogeneous nature of monocytes and their ability to differentiate into either monocyte-derived macrophages or monocyte-derived dendritic cells allows them to serve as a bridge between the innate and adaptive immune responses. Current studies of monocytes based on immunofluorescence, single-cell RNA sequencing and whole mass spectrometry finger printing reveals different classification systems for monocyte subsets. In humans, three circulating monocyte subsets are classified based on relative expression levels of CD14 and CD16 surface proteins, namely classical, intermediate and non-classical subsets. Transcriptomic analyses of these subsets help

Edited by:

Geanncarlo Lugo-Villarino,

UMR5089 Institut de

Pharmacologie et de Biologie

Structurale (IPBS), France

Reviewed by:

Masaaki Miyazawa,

Kindai University, Japan Werner Solbach,

Universität zu Lübeck, Germany

${ }^{*}$ Correspondence: Ramalingam Bethunaickan bramalingam@gmail.com, ramalingam.b@nirt.res.in

Specialty section: This article was submitted to Microbial Immunology, a section of the journal Frontiers in Immunology

Received: 13 December 2017 Accepted: 12 July 2018

Published: 30 July 2018

Citation:

Sampath P, Moideen K, Ranganathan UD and Bethunaickan R (2018) Monocyte Subsets: Phenotypes and Function in

Tuberculosis Infection.

Front. Immunol. 9:1726. doi: 10.3389/fimmu.2018.01726 to define their distinct functional properties. Tuberculosis (TB) is a disease instigated by the deadly pathogen Mycobacterium tuberculosis. Current research on monocytes in TB has indicated that there are alterations in the frequency of intermediate and non-classical subsets suggesting their impact in bacterial persistence. In this review, we will focus on these monocyte subsets, including their classification, frequency distribution, cytokine profiles, role as a biomarker and will comment on future directions for understanding the salient phenotypic and functional properties relevant to TB pathogenesis.

Keywords: monocyte subsets, $\mathrm{CD} 14^{+}$monocytes, $\mathrm{CD} 16^{+}$monocytes, biomarkers for tuberculosis, monocyte to lymphocyte ratio, monocyte signatures, Mycobacterium tuberculosis

\section{INTRODUCTION}

Mononuclear cells (monocytes/macrophages) are professional phagocytes that are highly skilled in defense against many pathogens including Mycobacterium tuberculosis (MTB). In MTB infection, the phenomenon of granuloma formation helps to isolate organisms and prevent their dissemination, besides, providing a niche for the survival of MTB without damage over long periods of time. Monocytes also participate in many other processes such as homeostasis, tumor surveillance, tissue repair, microbial resistance, maintenance of tissue integrity, apoptosis, necrosis, autophagy, etc. Advances in subset classification of mononuclear cells, their phenotypic and functional properties, and their modulation during disease conditions has stimulated research on identifying monocytederived biomarkers for diagnostic and treatment purposes.

\section{CIRCULATING MONOCYTES AND THEIR SUBSETS}

Human monocytes are bone marrow-derived leukocytes that circulate in the blood and can differentiate into monocyte-derived macrophages and monocyte-derived dendritic cells that govern innate and adaptive immune responses (1). These cells are heterogeneous in nature and exhibit 
high plasticity. Subset identification of monocytes is based on the relative expression of CD14 [co-receptor for toll-like receptor 4 (TLR4) and mediates lipopolysaccharide (LPS) signaling] and CD16 (Fc gamma receptor IIIa). Flow cytometric phenotyping has identified three different populations of monocytes namely, classical $\left(\mathrm{CD}_{14}^{++}, \mathrm{CD} 16^{-}\right)$, intermediate $\left(\mathrm{CD} 14^{+}, \mathrm{CD} 16^{+}\right)$, and non-classical $\left(\mathrm{CD}_{1} 4^{+}, \mathrm{CD} 16^{++}\right)$monocytes (2). The three monocyte subsets are phenotypically and functionally different. Earlier studies carried out by Murdoch et al. (3) and Venneri et al. (4) clearly identified two distinct populations of CD16 ${ }^{+}$ (intermediate and non-classical) monocytes based on the surface expression and function of the Tie- 2 marker. In addition, expression of Slan (6-sulfo LacNac) further distinguished the non-classical and intermediate monocyte subsets (5). However, the function of intermediate population is still not defined with some reports suggesting that they are related to the classical subset and others suggesting that they are related to the nonclassical subset. Classical monocytes comprise about $80-95 \%$ of circulating monocytes. These cells are highly phagocytic and are known to be important scavenger cells. Intermediate monocytes comprise about $2-8 \%$ of circulating monocytes. Their functions include production of reactive oxygen species (ROS), antigen presentation, participating in the proliferation and stimulation of $\mathrm{T}$ cells, inflammatory responses, and angiogenesis. Non-classical monocytes comprise about $2-11 \%$ of circulating monocytes. They are mobile in nature and patrol the endothelium in search of injury. They can have pro-inflammatory behavior and secrete inflammatory cytokines in response to infection. These cells are also involved in antigen presentation and T cell stimulation $(6,7)$. Phenotypic and functional differences of these subsets are listed in Table 1.

Subsets of monocytes have also been characterized and classified by various functional studies. Smedman et al. classified monocyte subsets into two groups based on cytokine induction by lipoteichoic acid and LPS; one larger population of cells secreting interleukin (IL)-1beta, IL-6, TNF-alpha, and CCL4 and a second smaller population of cells secreting GM-CSF, IL-10, and IL-12 p40 (31). Gren et al. using single-cell PCR gene expression identified 22 genes that are expressed by the classical population, 8 that characterize the intermediate population, and 6 that distinguish the non-classical population (32). Resting and activated monocyte subsets can be effectively distinguished using whole cell mass spectrometry fingerprinting (33). All these studies provide a platform to study further key details about monocyte phenotype and function, their behavior during disease and their interactions with pathogens.

\section{FUNCTIONAL ROLE OF MONOCYTE SUBSETS DEFINED BY TRANSCRIPTOMICS AND PROTEOMICS}

Transcriptomic, and proteomic studies can help to decode the functional variation within monocyte subsets. Classical monocytes mainly promote antimicrobial activity by characteristic upregulation of myeloperoxidase (MPO), lysozyme C precursor (LYZ), S100 calcium binding protein A9 (S100A9), eosinophil cationic protein precursor (RNase3), phospholipase B domain containing 1 (PLBD1), and Cathepsin G (CTSG), at both mRNA and protein levels $(13,34)$. Expression of pro-inflammatory mediators, particularly, S100A12, S100A9, and S100A8 is a hallmark of this subset, but other stimuli can potentially mediate even tissue repair functions, such as wound healing, angiogenesis, and coagulation $(6,13)$. Non-classical monocytes exhibit upregulation in the mRNA levels of heme oxygenase 1 (HMOX1), Villin 2 (VIL2), and Src family kinases constituting hemopoietic cell kinase (HCK) and tyrosineprotein kinase Lyn (LYN) and protein levels of actin related proteins (ARP2 and ARP3), HCK and LYN. These proteins phosphorylate the immunoreceptor tyrosine-based activation motif (ITAM) of Fc receptors leading to recruitment of downstream genes necessary for cytoskeletal remodeling suggesting a role for this macrophage subset in Fc receptor-mediated phagocytosis (34). In addition, upregulation of Rho GTPases, RhoC, and RhoF with their activators; guanine nucleotide exchange factors (VAV2 and ARH GEF18) and downstream effectors such as phosphatidylinositol5-phosphate 4-kinase, type II, alpha (PIP5K2A) and protein kinase N1 (PKN1) suggests that they undergo cytoskeletal rearrangement $(6,13)$. Non-classical subset do not secrete ROS or cytokines in response to cell-surface toll-like receptors. However, they secrete TNF-alpha, IL-1beta, and CCL3 in response to virus and immune complex containing nucleic acids via the MyD88MEK pathway (26). In depth proteome analysis further supports the established functions of classical and non-classical monocyte subsets (35).

A recent study performed by Villani et al. (14) defines the heterogeneity of intermediate monocyte subset based on single-cell RNA sequencing. They identified four monocyte subpopulations namely, Mono 1 (representing mostly the classical monocytes and some intermediate monocytes), Mono 2 (containing a major proportion of non-classical monocytes together with some intermediate monocytes), Mono 3, and Mono 4. These two newly identified Mono 3 and Mono 4 populations represent a major proportion of intermediate monocyte subsets and have unique expression of a set of genes along with co-expression of Mono 1 markers. Mono 3 subset expresses a unique combination of genes that affect cell cycle, differentiation, and trafficking, including MAX dimerization protein 1 (MXD1), C-X-C motif chemokine receptor 1 (CXCR1), C-X-C motif chemokine receptor 2 (CXCR2), and vascular non-inflammatory molecule 2 (VNN2). Mono 4 subset expresses a cytotoxic gene signature resembling that of natural killer dendritic cells including perforin 1, granulysin, and cathepsin W. Thus, it is evident that the earlier identified intermediate monocyte subset is highly heterogeneous in nature.

\section{MONOCYTES IN TUBERCULOSIS (TB)}

Current research focusing on monocytes and their subsets in $\mathrm{TB}$ has found that $\mathrm{CD}_{16} 6^{+}$monocytes are expanded in TB infection (36). Perturbation of this subset defines the severity of TB. Expansion of $\mathrm{CD} 16^{+}$monocytes is reversed with anti-TB treatment (37) suggesting this expansion is caused by microbial or host components (36). By contrast, tuberculin skin test (TST) positive individuals express higher $\mathrm{CD} 14^{+} \mathrm{CD} 16^{+}$monocyte subset than 
TABLE 1 | Phenotypic and functional differences of classical $\left(C D 14^{++}, C^{-16}\right)$, intermediate $\left(C D 14^{++}\right.$, CD16 $\left.^{+}\right)$, and non-classical monocyte $\left(\right.$CD14+, CD16 $\left.{ }^{++}\right)$subsets.

\begin{tabular}{|c|c|c|c|c|c|}
\hline & & Classical & Intermediate & Non-classical & Reference \\
\hline 1 & $\begin{array}{l}\text { Approximate proportions } \\
\text { of total monocytes }\end{array}$ & $80-95 \%$ & $2-11 \%$ & $2-8 \%$ & $\begin{array}{l}\text { Chimen et al. (7) } \\
\text { Yang et al. (8) } \\
\text { Wong et al. (9) } \\
\text { Shantsila et al. (10) } \\
\text { Ziegler-Heitbrock (11) } \\
\text { Passlick et al. (12) }\end{array}$ \\
\hline 2 & Size & $18 \mu \mathrm{m}$ & Intermediate & $14 \mu \mathrm{m}$ & Anbazhagan et al. (13) \\
\hline 3 & Differentiation potential & $\begin{array}{l}\text { Few macrophages and mostly } \\
\text { dendritic cells }\end{array}$ & $\begin{array}{l}\text { Non-homogenous population having } \\
\text { the potential to differentiate into some } \\
\text { macrophages and occasional cells } \\
\text { with dendrites }\end{array}$ & Mostly macrophages & $\begin{array}{l}\text { Villani et al. (14) } \\
\text { Boyette et al. (15) }\end{array}$ \\
\hline \multirow[t]{47}{*}{4} & $\begin{array}{l}\text { Surface markers and } \\
\text { gene signatures }\end{array}$ & $\mathrm{CD}^{4} 4^{++} \mathrm{CD}^{-} 6^{-}$ & $\mathrm{CD}_{14}^{++} \mathrm{CD}^{+} 6^{+}$ & CD14+ CD16 ${ }^{++}$ & \\
\hline & ACE & + & ++ & + & Boyette et al. (15) \\
\hline & CCR1 & +++ & + & $+/-$ & Ziegler-Heitbrock (16) \\
\hline & CCR2 & +++ & $+1-$ & - & Stansfield and Ingram (17) \\
\hline & CCR5 & ++ & +++ & $+/-$ & Anbazhagan et al. (13) \\
\hline & CD1d & +++ & ++ & $+/-$ & Hijdra et al. (18) \\
\hline & CD9 & +++ & ++ & $+/-$ & Wong et al. (9) \\
\hline & CD11a & + & + & ++ & Tallone et al. (19) \\
\hline & CD11b & +++ & +++ & $+/-$ & Wong et al. (6) \\
\hline & CD11c & $+/-$ & + & +++ & Zawada et al. (20) \\
\hline & CD32 & + & +++ & ++ & Rogacev et al. (21) \\
\hline & CD33 & +++ & ++ & $+/-$ & Ulrich et al. (22) \\
\hline & CD36 & +++ & ++ & $+/-$ & Ingersoll et al. (23) \\
\hline & CD40 & $+/-$ & +++ & ++ & Sunderkotter et al. (24) \\
\hline & $\mathrm{CD} 43$ & - & + & ++ & Ancuta et al. (25) \\
\hline & CD47 & ++ & +++ & ++ & \\
\hline & CD54 & + & +++ & ++ & \\
\hline & CD62L & + & ++ & - & \\
\hline & CD64 & +++ & +++ & $+/-$ & \\
\hline & CD80 & + & +++ & $+/-$ & \\
\hline & CD86 & + & +++ & ++ & \\
\hline & CD97 & + & ++ & +++ & \\
\hline & CD99 & +++ & + & $+/-$ & \\
\hline & CD115 & + & ++ & +++ & \\
\hline & CD123 & $+/-$ & ++ & +++ & \\
\hline & CD163 & ++ & +++ & $+/-$ & \\
\hline & CD294 & $+/-$ & ++ & +++ & \\
\hline & CLEC4D & +++ & $+/-$ & - & \\
\hline & CLEC5A & +++ & $+/-$ & - & \\
\hline & CLEC10a & $+/-$ & ++ & $+/-$ & \\
\hline & CXCR1 & +++ & $+/-$ & - & \\
\hline & CXCR2 & +++ & $+/-$ & - & \\
\hline & CXCR4 & +++ & ++ & $+/-$ & \\
\hline & CX3CR1 & $+/-$ & ++ & +++ & \\
\hline & GFR $\alpha 2$ & $+/-$ & +++ & + & \\
\hline & HLA-ABC & ++ & +++ & + & \\
\hline & HLA-DR & $+/-$ & +++ & ++ & \\
\hline & IL13R $\alpha 1$ & +++ & $+/-$ & - & \\
\hline & $\mathrm{MHCl}$ & + & ++ & + & \\
\hline & PSGL-1 & ++ & + & + & \\
\hline & P2RX1 & $+/-$ & ++ & +++ & \\
\hline & Siglec10 & $+/-$ & + & +++ & \\
\hline & $\operatorname{SIRP} \alpha$ & + & ++ & +++ & \\
\hline & SLAN & + & $+/-$ & +++ & \\
\hline & Tie2 & - & + & $+/-$ & \\
\hline & TNFR1 & + & +++ & + & \\
\hline & TNFR2 & + & ++ & +++ & \\
\hline 5 & $\begin{array}{l}\text { Preferred response to } \\
\text { LPS }\end{array}$ & $\begin{array}{l}\text { IL-10, G-CSF, CCL2, CCL5, IL-6, } \\
\text { IL-8, TNF-alpha }\end{array}$ & IL-6, IL-8, TNF-alpha & $\begin{array}{l}\text { TNF-alpha, IL-1 beta, IL-6, IL-8, } \\
\text { CCL3 (in response to virus } \\
\text { rather than LPS) }\end{array}$ & $\begin{array}{l}\text { Boyette et al. (15) } \\
\text { Wong et al. (9) } \\
\text { Cros et al. (26) }\end{array}$ \\
\hline
\end{tabular}


TABLE 1 | Continued

\begin{tabular}{|c|c|c|c|c|c|}
\hline & & Classical & Intermediate & Non-classical & Reference \\
\hline 6 & $\begin{array}{l}\text { Gene signature derived } \\
\text { functions }\end{array}$ & $\begin{array}{l}\text { Superior phagocytosis, high MPO } \\
\text { activity, high antibody-dependent } \\
\text { cell-mediated cytotoxicity, } \\
\text { increased skin homing potential, } \\
\text { wound healing, coagulation, tissue } \\
\text { repair, pro-inflammatory (S-100 } \\
\text { proteins), scavenger receptors, } \\
\text { C-type lectin receptors, anti- } \\
\text { apoptosis, proliferative, response } \\
\text { to various stimuli, antibacterial, } \\
\text { more plasticity }\end{array}$ & $\begin{array}{l}\text { T cell proliferation and stimulation, } \\
\text { superior ROS production, } \\
\text { angiogenesis (Tie-2 subpopulation), } \\
\text { MHC class II presentation and } \\
\text { processing, cell differentiation }\end{array}$ & $\begin{array}{l}\text { T cell proliferation and } \\
\text { stimulation (SLAN } \\
\text { subpopulation), patrolling } \\
\text { behavior in vivo, better } \\
\text { in Fc receptor-mediated } \\
\text { phagocytosis, cytoskeletal } \\
\text { rearrangement, complement } \\
\text { components, pro-apoptosis, } \\
\text { anti-proliferative, negative } \\
\text { regulation of transcription, } \\
\text { antiviral response, pro- } \\
\text { angiogenic behavior }\end{array}$ & $\begin{array}{l}\text { Lastrucci et al. (27) } \\
\text { Anbazhagan et al. (13) } \\
\text { Wong et al. (9) } \\
\text { Wong et al. (6) } \\
\text { Robbins and Swirski (28) } \\
\text { Cros et al. (26) } \\
\text { Martinez (29) } \\
\text { Mobley et al. (30) }\end{array}$ \\
\hline
\end{tabular}

Present tetanus toxoid and other particulate antigens, produce reactive nitrogen intermediates, increased gut homing potential, increased expression of pro-inflammatory genes and co-stimulatory molecules

IL, interleukins; TNF, tumor necrosis factor; G-CSF, granulocyte colony-stimulating factor; CCL, C-C motif chemokine ligand; MPO, myeloperoxidase; CXCR1, C-X-C motif chemokine receptor 1; CXCR2, C-X-C motif chemokine receptor 2; LPS, lipopolysaccharide; ROS, reactive oxygen species.

either active TB patients or healthy TST negative controls, suggesting that these cells constitute an innate protective mechanism against TB in such individuals (38). This finding has, however, not been well-reproduced. For example Castano et al. (36), did not find significant differences in the monocyte subpopulations between TST-positive individuals and TB patients except for higher CD11b and low HLA-DR surface marker expression in non-classical monocytes.

Castano et al. (36) focused on the differences among the three monocyte subsets between TB patients and healthy individuals. In their study, the percentage of intermediate and non-classical monocytes was increased and classical monocyte was decreased in TB patients. There was also an alteration in the profile of monocyte subsets in TB patients. Classical monocytes and intermediate monocytes of TB patients exhibited a lower expression of CD11b and CCR5 and higher expression of CD80, CD86, non-specific esterase (NSE), and CCR2 when compared with healthy individuals. In addition, intermediate monocytes showed higher expression of CD40 and CD68. CD16 ${ }^{+}$monocytes did not differentiate into macrophages due to limited expression of maturation and differentiation markers such as CD11b, CD11c, CD33, and CD36 (36). Non-classical monocytes of TB patients exhibited a lower expression of CD11c, CD33, CD36, HLA-DR, and CCR5 and higher expression of CD11b, CD40, CD80, NSE, and CCR2. These studies suggest a potential role of intermediate monocytes in $\mathrm{T}$ cell activation, proliferation, and antigen presentation.

When compared to $\mathrm{CD}^{+} 6^{+}$monocytes, $\mathrm{CD}^{-} 6^{-}$(classical) monocytes confer anti-mycobacterial immune responses during TB infection such as enhanced in vitro migration in response to mycobacterial derivatives, higher production of ROS, higher lung migration index, and induction of strong pulmonary infiltration. It has been suggested that immediate infiltration of these subsets to the infection site and the production of ROS results in reduction of bacterial growth. By contrast, CD16 ${ }^{+}$monocytes are involved in promoting bacterial resilience (39). This subset induces a minimal level of respiratory burst and is unresponsive at early stages of infection due to the lack of chemokine receptors (CCR2) necessary for the migration of this subset to the infection site. Similarly, earlier studies have reported that $\mathrm{CD} 16^{+}$subset upregulates CCR2 expression during disease severity which aims to improve their migration ability toward the infection (40). Upregulation of CD11b within $\mathrm{CD}^{+} 6^{+}$monocytes suggests a possible way for intracellular survival of MTB and the loss of HLA-DR confers inefficient antigen presentation potency which leads to disease severity (41). Differential induction of a response to purified protein derivative (PPD) and MTB has been displayed by monocytes obtained from PPD skin test-positive individuals and active TB patients. PPD could induce apoptosis in both groups of subjects, whereas induction with MTB resulted in necrosis only among active TB patients, suggesting that apoptosis can influence the protective ability of the host (42).

Studies carried out by Balboa et al. (43), revealed that CD16 ${ }^{+}$ monocytes from active TB patients have a poor capability to differentiate into functional dendritic cells due to high level of phosphorylated p38 MAP kinase. They have also reported differences in the dendritic cell profile among healthy (DC SIGN ${ }^{\text {high }}$ and $\mathrm{CD} \mathrm{a}^{+}$) and active TB (DC SIGN ${ }^{\text {low }}$ and CD86 $6^{\text {high }}$ ) subjects. This impairs their differentiation of monocytes to monocyte-derived dendritic cells and their antigen-presenting cell functions (44) resulting in a decrease in their ability to mount strong adaptive responses toward infection.

Mycobacterium tuberculosis has the ability to modulate the macrophage response and induce the secretion of anti-inflammatory cytokines such as IL-10 thereby modulating the differentiation of $\mathrm{CD} 14^{+} \mathrm{CD} 16^{-}$monocytes toward the M2 activation program $\left(\mathrm{CD}_{16}{ }^{+} \mathrm{CD}_{163}{ }^{+} \mathrm{MerTK}^{+} \mathrm{pSTAT} 3^{+}\right)$in a STAT3-dependent manner. This leads to enhanced protease-dependent motility making them permissive for intracellular MTB survival with reduced ability to produce pro-inflammatory cytokines (27).

\section{CYTOKINE PROFILE OF MONOCYTES DURING TB INFECTION}

Only limited studies have focused on the cytokine expression of monocytes and their subsets during TB infection. Upon MTB infection, $\mathrm{CD}^{-} 6^{-}$monocytes produce IL-10 which results in a 
higher frequency of $\mathrm{CD} 16^{+}$monocytes. Adoptive transfer studies of $\mathrm{CD}_{16}{ }^{+}$and $\mathrm{CD}^{-} 6^{-}$monocytes within SCID/Beige mice infected with MTB showed that mice receiving $\mathrm{CD}^{-} 6^{-}$monocytes produce higher IL-10 and TGF-beta and mice receiving CD16 ${ }^{+}$ monocytes produced higher TNF-alpha. CD16 ${ }^{-}$monocytes exhibit both pro- and anti-inflammatory cytokine production besides leukocyte recruitment under infectious conditions, whereas, $\mathrm{CD}_{16} 6^{+}$monocytes induce IL-1beta production and leukocyte recruitment under non-infectious conditions (39). In work by Castano et al. (36), classical monocytes produce less TNF-alpha and more IL-10 whereas intermediate and nonclassical monocytes produce less IL-10 and more TNF-alpha. $\mathrm{CD}_{16} 6^{+}$monocytes are involved in promoting the disease, but in vitro production of TNF-alpha by these cells helps to control TB infection. In addition, differential cytokine production by $\mathrm{CD}_{1} 6^{+}$monocytes was observed in response to live vs. dead MTB. Dead MTB induced lower TNF-alpha and IL-8 compared to live MTB as a result of differences in their cell wall structure and components (45). However, it is still not known which subset of $\mathrm{CD}_{16}{ }^{+}$monocytes is actually producing TNF-alpha.

\section{MONOCYTE TO LYMPHOCYTE RATIO (ML RATIO)}

Monocyte to lymphocyte ratio is considered an important criterion to determine the immune efficiency of an individual during infectious conditions and is easily quantified in the peripheral blood. During MTB infection, there have been evolving reports suggesting that an increased ratio of monocytes to lymphocytes in comparison with healthy donors denotes the severity of active TB. A high ML ratio may also serve as an indicator of the effectiveness of anti-TB treatment (46) since it normalizes following treatment. Studies by La Manna et al. (47) and Wang et al. (48) suggest that the ML ratio can also be used as a marker to predict the risk of developing active TB. A study by Rakotosamimanana et al. (49), suggested that TST along with ML ratio may predict the risk for the development of TB in contacts. In vitro studies performed by Naranbhai et al. (50) showed that ML ratio is related to MTB growth and thereby related to the stage of TB. Naranbhai et al. (51) performed a study of ML ratio in 3-4 month infants and found that an elevated ML ratio is directly correlated with the increased risk for the development of TB before 2 years of age. Though ML ratio seems to be a well-suited prognostic marker in defining the risk for TB as well as the efficiency of treatment, the reliability of this marker remains to be confirmed and it is not known whether it correlates with any other diseases or inflammatory conditions. Further prospective studies in larger cohorts will help to define the role of ML ratio in TB prognosis and management.

\section{BIOMARKERS}

Biomarkers are considered to be a critical component of management of all diseases including TB. Biomarkers are the key factors that can help in determining disease stage, early diagnosis, predicting the behavior of pathogens within the host immune system, and the response of host immune cells toward the pathogen and the disease. Biomarkers may also help to determine treatment and to protect from future complications. Numerous transcriptomic approaches have revealed biomarkers for TB expressed by monocytes. ML ratio as discussed in the previous section can also be considered as a biomarker for TB. Some of the biomarkers identified by the researchers for TB are described in Table 2.

Although many biomarkers for TB based on monocytes have been suggested are available, they need to be validated in larger patient cohorts. In addition, the cost, time, and the conditions for performing reproducible assays need to be established so that they can be used in rural areas where TB is endemic. These are challenging considerations that will require much future work.

\section{CURRENT RESEARCH GAPS AND FUTURE RESEARCH}

Although many studies exploring monocytes and their subsets have been performed in TB, further studies on monocyte subsets, particularly $\mathrm{CD}_{16}{ }^{+}$intermediate monocytes are still needed to fill the gaps in knowledge.

- Limited studies have been performed that investigate the role of $\mathrm{CD}_{16} 6^{+}$monocyte subsets in TB. Animal studies may be helpful to correlate their function and phenotype with respect to disease progression and protection.

- Recent studies have documented perturbation of the CD16 intermediate monocyte subset upon infection with MTB, suggesting that this cell type favors the intracellular survival of MTB. More studies are needed to document the dysfunction of this subset with reference to their differentiation ability, antigen recognition potency, migration behavior, phagocytic properties, immunostimulation, autophagy, apoptosis, metabolic program, and the mechanism of pathogen clearance. These studies will be helpful to develop newer host directed therapies.

- Although IL-10 contribute to the expansion of CD16 $6^{+}$monocytes, other factors such as the antigenic components of MTB (secreted and membrane bound antigens) and the host environment (antigen presentation), can favor the expansion of $\mathrm{CD}_{16}{ }^{+}$monocytes. More work is needed to identify the factors involved in the expansion of $\mathrm{CD} 16^{+}$monocytes in established mycobacterial infection.

- Molecular profiling of sorted monocyte subsets of infected patients will be helpful to identify their unique functions. Exploring the phenotype and function of monocyte subsets in granulomas through in vivo animal studies could provide the clues about the intracellular survival of MTB and help to decipher the pathophysiology of TB. Newer techniques such as CyTOF and MALDI-TOF could be employed to identify additional phenotypes within sorted monocyte subsets. Single-cell transcriptomic studies involving RNAseq, miRNome, and/or epigenetic profiling needs to be performed in order to understand the functional roles and transcriptional regulation of the different subsets.

- Metabolomic profiles of classical and non-classical monocytes have been very well studied. Substantial insights into the underlying mechanisms of metabolic switches within intermediate 
TABLE 2 | List of identified biomarkers based on monocytes for tuberculosis (TB).

\begin{tabular}{|c|c|c|c|c|c|}
\hline Biomarkers & Signature & Functions & $\begin{array}{l}\text { Expressed } \\
\text { by }\end{array}$ & Able to & Reference \\
\hline FPR1 & Formyl peptide receptor 1 & Pro-inflammatory, antimicrobial defense & $\begin{array}{l}\text { Professional } \\
\text { phagocytes }\end{array}$ & & $\begin{array}{l}\text { Jacobsen } \\
\text { et al. (52) }\end{array}$ \\
\hline \multirow[t]{5}{*}{$\begin{array}{l}\text { Combination } \\
\text { of CD64, LTF, } \\
\text { and RaB33a }\end{array}$} & $\begin{array}{l}\text { CD64 } \\
\text { Fc gamma receptor la }\end{array}$ & $\begin{array}{l}\text { Induce phagocytosis, respiratory burst and antibody- } \\
\text { dependent cell-mediated cytotoxicity in monocytes, } \\
\text { macrophages, and granulocytes }\end{array}$ & \multirow[t]{5}{*}{ Monocytes } & \multirow[t]{5}{*}{$\begin{array}{l}\text { Discriminate } \\
\text { active TB, latent } \\
\text { TB infection, and } \\
\text { healthy status }\end{array}$} & \\
\hline & LTF & & & & \\
\hline & $\begin{array}{l}\text { Lactoferrin is a transport } \\
\text { molecule with high affinity for iron }\end{array}$ & $\begin{array}{l}\text { Modulates the host response by competing with the microbes } \\
\text { for iron }\end{array}$ & & & \\
\hline & Rab33a & & & & \\
\hline & $\begin{array}{l}\text { Member of Ras-associated small } \\
\text { GTPase family }\end{array}$ & Regulates intracellular trafficking & & & \\
\hline $\begin{array}{l}\mathrm{mCD} 14 \\
\text { receptor }\end{array}$ & $\begin{array}{l}\text { Membrane bound CD14 } \\
\text { receptor }-55 \mathrm{kD} \text { glycoprotein }\end{array}$ & $\begin{array}{l}\text { Pattern recognition receptor for Mycobacterium tuberculosis } \\
\text { components such as LAM and lipoproteins }\end{array}$ & Monocytes & $\begin{array}{l}\text { Biomarker for active } \\
\text { TB }\end{array}$ & $\begin{array}{l}\text { Druszczynska } \\
\text { et al. (53) }\end{array}$ \\
\hline HMBG1 & $\begin{array}{l}\text { High mobility group box } 1 \text { protein } \\
\text { also known as Amphoterin }\end{array}$ & $\begin{array}{l}\text { Pro-inflammatory cytokine, serves as DAMP to alert the innate } \\
\text { immune system by recruiting inflammatory cells during disease } \\
\text { condition, acts as an immune adjuvant to trigger the response } \\
\text { of T cells, dendritic cells, and endothelial cells }\end{array}$ & Monocytes & $\begin{array}{l}\text { Biomarker for active } \\
\text { TB }\end{array}$ & $\begin{array}{l}\text { Zeng } \\
\text { et al. (54) }\end{array}$ \\
\hline IL26 & $\begin{array}{l}\text { Member of interleukin-10 } \\
\text { cytokine family }\end{array}$ & Inhibitory effect on anti-mycobacterial activity & Monocytes & $\begin{array}{l}\text { Susceptible gene } \\
\text { for TB }\end{array}$ & $\begin{array}{l}\text { Guerra-Laso } \\
\text { et al. (55) }\end{array}$ \\
\hline CD163 & $\begin{array}{l}\text { Monocyte/macrophage specific } \\
\text { glycoprotein }\end{array}$ & Scavenger receptor & Monocytes & $\begin{array}{l}\text { Biomarker for TB } \\
\text { disease progression } \\
\text { and monitor } \\
\text { treatment efficacy }\end{array}$ & $\begin{array}{l}\text { Lastrucci } \\
\text { et al. (27) }\end{array}$ \\
\hline
\end{tabular}

monocyte subsets may provide novel tools to identify their cellular function during mycobacterial infection. Drugs inducing metabolic switches can be tested for the treatment of TB.

- Studies of monocyte-related biomarkers in patients of different ethnicities should be encouraged. Previously reported biomarkers need to be validated in larger clinical cohorts including extra pulmonary TB and other infectious or inflammatory conditions in order to delineate their specificity.

\section{CONCLUSION}

Our review describes the phenotypic and functional variations within monocyte subsets, with reference to mycobacterial infection. With further understanding, we may be able to identify a possible mechanism for the intracellular survival of MTB and to decipher the clues behind the host immune response that influences TB pathogenesis. Current knowledge gaps and suggested future research on monocyte subsets also include better

\section{REFERENCES}

1. Guilliams M, Ginhoux F, Jakubzick C, Naik SH, Onai N, Schraml BU, et al. Dendritic cells, monocytes and macrophages: a unified nomenclature based on ontogeny. Nat Rev Immunol (2014) 14(8):571-8. doi:10.1038/nri3712

2. Ziegler-Heitbrock L, Ancuta P, Crowe S, Dalod M, Grau V, Hart DN, et al. Nomenclature of monocytes and dendritic cells in blood. Blood (2010) 116(16):e74-80. doi:10.1182/blood-2010-02-258558

3. Murdoch C, Tazzyman S, Webster S, Lewis CE. Expression of Tie-2 by human monocytes and their responses to angiopoietin-2. J Immunol (2007) 178(11):7405-11. doi:10.4049/jimmunol.178.11.7405 definition of biomarkers for early diagnosis or prognosis of disease and exploration of newer host directed therapies to combat mycobacterial infection.

\section{AUTHOR CONTRIBUTIONS}

PS and RB: drafting and revising the article, concept and design. KM: contributed to writing. UR: revision of the article; concept and design.

\section{ACKNOWLEDGMENTS}

The authors would like to sincerely thank Dr. Anne Davidson, Investigator, Feinstein Institute for Medical Research, New York, USA, for critical reading of the manuscript. PS work has been supported by DST INSPIRE fellowship and RB's work has been supported by the DBT Ramalingaswami Fellowship, Ministry of Science and Technology, Government of India.

4. Venneri MA, De Palma M, Ponzoni M, Pucci F, Scielzo C, Zonari E, et al Identification of proangiogenic TIE2-expressing monocytes (TEMs) in human peripheral blood and cancer. Blood (2007) 109(12):5276-85. doi:10.1182/ blood-2006-10-053504

5. Hofer TP, Zawada AM, Frankenberger M, Skokann K, Satzl AA, Gesierich W, et al. Slan-defined subsets of CD16-positive monocytes: impact of granulomatous inflammation and M-CSF receptor mutation. Blood (2015) 126(24):2601-10. doi:10.1182/blood-2015-06-651331

6. Wong KL, Tai JJ, Wong WC, Han H, Sem X, Yeap WH, et al. Gene expression profiling reveals the defining features of the classical, intermediate, and nonclassical human monocyte subsets. Blood (2011) 118(5):e16-31. doi:10.1182/blood-2010-12-326355 
7. Chimen M, Yates CM, McGettrick HM, Ward LS, Harrison MJ, Apta B, et al. Monocyte subsets coregulate inflammatory responses by integrated signaling through TNF and IL-6 at the endothelial cell interface. J Immunol (2017) 198(7):2834-43. doi:10.4049/jimmunol.1601281

8. Yang J, Zhang L, Yu C, Yang XF, Wang H. Monocyte and macrophage differentiation: circulation inflammatory monocyte as biomarker for inflammatory diseases. Biomark Res (2014) 2(1):1. doi:10.1186/2050-7771-2-1

9. Wong KL, Yeap WH, Tai JJ, Ong SM, Dang TM, Wong SC. The three human monocyte subsets: implications for health and disease. Immunol Res (2012) 53(1-3):41-57. doi:10.1007/s12026-012-8297-3

10. Shantsila E, Wrigley B, Tapp L, Apostolakis S, Montoro-Garcia S, Drayson MT, et al. Immunophenotypic characterization of human monocyte subsets: possible implications for cardiovascular disease pathophysiology. J Thromb Haemost (2011) 9(5):1056-66. doi:10.1111/j.1538-7836.2011.04244.x

11. Ziegler-Heitbrock HW. Definition of human blood monocytes. J Leukoc Biol (2000) 67(5):603-6. doi:10.1002/jlb.67.5.603

12. Passlick B, Flieger D, Ziegler-Heitbrock HW. Identification and characterization of a novel monocyte subpopulation in human peripheral blood. Blood (1989) 74(7):2527-34.

13. Anbazhagan K, Duroux-Richard I, Jorgensen C, Apparailly F. Transcriptomic network support distinct roles of classical and non-classical monocytes in human. Int Rev Immunol (2014) 33(6):470-89. doi:10.3109/08830185.2014. 902453

14. Villani AC, Satija R, Reynolds G, Sarkizova S, Shekhar K, Fletcher J, et al. Single-cell RNA-seq reveals new types of human blood dendritic cells, monocytes, and progenitors. Science (2017) 356(6335):eaah4573. doi:10.1126/ science.aah4573

15. Boyette LB, Macedo C, Hadi K, Elinoff BD, Walters JT, Ramaswami B, et al. Phenotype, function, and differentiation potential of human monocyte subsets. PLoS One (2017) 12(4):e0176460. doi:10.1371/journal.pone.0176460

16. Ziegler-Heitbrock L. Blood monocytes and their subsets: established features and open questions. Front Immunol (2015) 6:423. doi:10.3389/fimmu.2015. 00423

17. Stansfield BK, Ingram DA. Clinical significance of monocyte heterogeneity. Clin Transl Med (2015) 4:5. doi:10.1186/s40169-014-0040-3

18. Hijdra D, Vorselaars AD, Grutters JC, Claessen AM, Rijkers GT. Phenotypic characterization of human intermediate monocytes. Front Immunol (2013) 4:339. doi:10.3389/fimmu.2013.00339

19. Tallone T, Turconi G, Soldati G, Pedrazzini G, Moccetti T, Vassalli G. Heterogeneity of human monocytes: an optimized four-color flow cytometry protocol for analysis of monocyte subsets. JCardiovasc Trans Res (2011) 4(2):211-9. doi:10.1007/s12265-011-9256-4

20. Zawada AM, Rogacev KS, Rotter B, Winter P, Marell RR, Fliser D, et al. SuperSAGE evidence for CD14++CD16+ monocytes as a third monocyte subset. Blood (2011) 118(12):e50-61. doi:10.1182/blood-2011-01-326827

21. Rogacev KS, Seiler S, Zawada AM, Reichart B, Herath E, Roth D, et al. CD14++CD16+ monocytes and cardiovascular outcome in patients with chronic kidney disease. Eur Heart J (2011) 32(1):84-92. doi:10.1093/eurheartj/ ehq371

22. Ulrich C, Heine GH, Seibert E, Fliser D, Girndt M. Circulating monocyte subpopulations with high expression of angiotensin-converting enzyme predict mortality in patients with end-stage renal disease. Nephrol Dial Transplant (2010) 25(7):2265-72. doi:10.1093/ndt/gfq012

23. Ingersoll MA, Spanbroek R, Lottaz C, Gautier EL, Frankenberger M, Hoffmann R, et al. Comparison of gene expression profiles between human and mouse monocyte subsets. Blood (2010) 115(3):e10-9. doi:10.1182/ blood-2009-07-235028

24. Sunderkotter C, Nikolic T, Dillon MJ, Van Rooijen N, Stehling M, Drevets DA, et al. Subpopulations of mouse blood monocytes differ in maturation stage and inflammatory response. J Immunol (2004) 172(7):4410-7. doi:10.4049/ jimmunol.172.7.4410

25. Ancuta P, Rao R, Moses A, Mehle A, Shaw SK, Luscinskas FW, et al. Fractalkine preferentially mediates arrest and migration of CD16+ monocytes. J Exp Med (2003) 197(12):1701-7. doi:10.1084/jem.20022156

26. Cros J, Cagnard N, Woollard K, Patey N, Zhang SY, Senechal B, et al. Human CD14dim monocytes patrol and sense nucleic acids and viruses via TLR7 and TLR8 receptors. Immunity (2010) 33(3):375-86. doi:10.1016/j. immuni.2010.08.012
27. Lastrucci C, Benard A, Balboa L, Pingris K, Souriant S, Poincloux R, et al. Tuberculosis is associated with expansion of a motile, permissive and immunomodulatory CD16+ monocyte population via the IL-10/STAT3 axis. Cell Res (2015) 25(12):1333-51. doi:10.1038/cr.2015.123

28. Robbins CS, Swirski FK. The multiple roles of monocyte subsets in steady state and inflammation. Cell Mol Life Sci (2010) 67(16):2685-93. doi:10.1007/ s00018-010-0375-x

29. Martinez FO. The transcriptome of human monocyte subsets begins to emerge. J Biol (2009) 8(11):99. doi:10.1186/jbiol206

30. Mobley JL, Leininger M, Madore S, Baginski TJ, Renkiewicz R. Genetic evidence of a functional monocyte dichotomy. Inflammation (2007) 30(6):189-97. doi:10.1007/s10753-007-9036-0

31. Smedman C, Ernemar T, Gudmundsdotter L, Gille-Johnson P, Somell A, Nihlmark K, et al. Fluorospot analysis of TLR-activated monocytes reveals several distinct cytokine-secreting subpopulations. Scand J Immunol (2011) 75(2):249-58. doi:10.1111/j.1365-3083.2011.02641.x

32. Gren ST, Rasmussen TB, Janciauskiene S, Håkansson K, Gerwien JG, Grip O. A single-cell gene-expression profile reveals inter-cellular heterogeneity within human monocyte subsets. PLoS One (2015) 10(12):e0144351. doi:10.1371/ journal.pone.0144351

33. Portevin D, Pflüger V, Otieno P, Brunisholz R, Vogel G, Daubenberger C. Quantitative whole-cell MALDI-TOF MS fingerprints distinguishes human monocyte sub-populations activated by distinct microbial ligands. $B M C$ Biotechnol (2015) 15:24. doi:10.1186/s12896-015-0140-1

34. Zhao C, Zhang H, Wong WC, Sem X, Han H, Ong SM, et al. Identification of novel functional differences in monocyte subsets using proteomic and transcriptomic methods. J Proteome Res (2009) 8(8):4028-38. doi:10.1021/ pr900364p

35. Segura V, Valero ML, Cantero L, Muñoz J, Zarzuela E, García F, et al. In-depth proteomic characterization of classical and non-classical monocyte subsets. Proteomes (2018) 6(1):8. doi:10.3390/proteomes6010008

36. Castano D, Garcia LF, Rojas M. Increased frequency and cell death of CD16+ monocytes with Mycobacterium tuberculosis infection. Tuberculosis (Edinb) (2011) 91:348-60. doi:10.1016/j.tube.2011.04.002

37. Sanchez MD, Garcia Y, Montes C, Paris SC, Rojas M, Barrera LF, et al. Functional and phenotypic changes in monocytes from patients with tuberculosis are reversed with treatment. Microbes Infect (2006) 8(9-10):2492-500. doi:10.1016/j.micinf.2006.06.005

38. Barcelos W, Sathler-Avelar R, Martins-Filho OA, Carvalho BN, Guimaraes TM, Miranda SS, et al. Natural killer cell subpopulations in putative resistant individuals and patients with active Mycobacterium tuberculosis infection. Scand J Immunol (2008) 68(1):92-102. doi:10.1111/j.1365-3083.2008.02116.x

39. Balboa L, Barrios-Payan J, Gonzalez-Dominguez E, Lastrucci C, LugoVillarino G, Mata-Espinoza D, et al. Diverging biological roles among human monocyte subsets in the context of tuberculosis infection. Clin Sci (Lond) (2015) 129(4):319-30. doi:10.1042/CS20150021

40. Balboa L, Romero MM, Basile JI, Sabio y García CA, Schierloh P, Yokobori N, et al. Paradoxical role of CD16+CCR2+CCR5+ monocytes in tuberculosis: efficient APC in pleural effusion but also mark disease severity in blood. J Leukoc Biol (2011) 90(1):69-75. doi:10.1189/jlb.1010577

41. Malik ZA, Denning GM, Kusner DJ. Inhibition of Ca (2+) signaling by Mycobacterium tuberculosis is associated with reduced phagosome-lysosome fusion and increased survival within human macrophages. J Exp Med (2000) 191(2):287-302. doi:10.1084/jem.191.2.287

42. Gil DP, León LG, Correa LI, Maya JR, París SC, García LF, et al. Differential induction of apoptosis and necrosis in monocytes from patients with tuberculosis and healthy control subjects. J Infect Dis (2004) 189(11):2120-8. doi: $10.1086 / 386369$

43. Balboa L, Romero MM, Laborde E, Sabio Y Garcia CA, Basile JI, Schierloh P, et al. Impaired dendritic cell differentiation of CD16-positive monocytes in tuberculosis: role of p38 MAPK. Eur J Immunol (2013) 43:335-47. doi:10.1002/ eji.201242557

44. Lugo-Villarino G, Neyrolles O. Dressed not to kill: CD16+ monocytes impair immune defense against tuberculosis. Eur J Immunol (2013) 43(2):327-30. doi:10.1002/eji.201243256

45. Shimada K, Takimoto H, Yano I, Kumazawa Y. Involvement of mannose receptor in glycopeptidolipid-mediated inhibition of phagosome-lysosome fusion. Microbiol Immunol (2006) 50:243.e51. doi:10.1111/j.1348-0421.2006.tb03782.x 
46. Iqbal S, Ahmed U, Zaidi SBH. Monocyte lymphocyte ratio as a possible prognostic marker in antituberculous therapy. J Rawalpindi Med Coll (JRMC) (2014) 18(2):178-81.

47. La Manna MP, Orlando V, Dieli F, Di Carlo P, Cascio A, Cuzzi G, et al. Quantitative and qualitative profiles of circulating monocytes may help identifying tuberculosis infection and disease stages. PLoS One (2017) 12(2):e0171358. doi:10.1371/journal.pone.0171358

48. Wang J, Yin Y, Wang X, Pei H, Kuai S, Gu L, et al. Ratio of monocytes to lymphocytes in peripheral blood in patients diagnosed with active tuberculosis. Braz J Infect Dis (2015) 19(2):125-31. doi:10.1016/j.bjid.2014. 10.008

49. Rakotosamimanana N, Richard V, Raharimanga V, Gicquel B, Doherty TM, Zumla A, et al. Biomarkers for risk of developing active tuberculosis in contacts of TB patients: a prospective cohort study. Eur Respir J (2015) 46(4):1095-103. doi:10.1183/13993003.00263-2015

50. Naranbhai V, Fletcher HA, Tanner R, O'Shea MK, McShane H, Fairfax BP, et al. Distinct transcriptional and anti-mycobacterial profiles of peripheral blood monocytes dependent on the ratio of monocytes: lymphocytes. EBioMedicine (2015) 2(11):1619-26. doi:10.1016/j.ebiom.2015.09.027

51. Naranbhai V, Kim S, Fletcher H, Cotton MF, Violari A, Mitchell C, et al. The association between the ratio of monocytes: lymphocytes at age 3 months and risk of tuberculosis (TB) in the first two years of life. BMC Med (2014) 12:120. doi:10.1186/s12916-014-0120-7

52. Jacobsen M, Repsilber D, Gutschmidt A, Neher A, Feldmann K, Mollenkopf HJ, et al. Candidate biomarkers for discrimination between infection and disease caused by Mycobacterium tuberculosis. J Mol Med (Berl) (2007) 85(6):613-21. doi:10.1007/s00109-007-0157-6

53. Druszczynska M, Wlodarczyk M, Janiszewska-Drobinska B, Kielnierowski G, Zawadzka J, Kowalewicz-Kulbat M, et al. Monocyte signal transduction receptors in active and latent tuberculosis. Clin Dev Immunol (2013) 2013:851452. doi:10.1155/2013/851452

54. Zeng JC, Xiang WY, Lin DZ, Zhang JA, Liu GB, Kong B. Elevated HMGB1related interleukin- 6 is associated with dynamic responses of monocytes in patients with active pulmonary tuberculosis. Int J Clin Exp Pathol (2015) $8(2): 1341-53$.

55. Guerra-Laso JM, Raposo-García S, Garcia-Garcia S, Diez-Tascon C, RiveroLezcano OM. Microarray analysis of Mycobacterium tuberculosis-infected monocytes reveals IL26 as a new candidate gene for tuberculosis susceptibility. Immunology (2015) 144(2):291-301. doi:10.1111/imm.12371

Conflict of Interest Statement: The authors declare that the research was conducted in the absence of any commercial or financial relationships that could be construed as a potential conflict of interest.

Copyright (c) 2018 Sampath, Moideen, Ranganathan and Bethunaickan. This is an open-access article distributed under the terms of the Creative Commons Attribution License (CC BY). The use, distribution or reproduction in other forums is permitted, provided the original author(s) and the copyright owner(s) are credited and that the original publication in this journal is cited, in accordance with accepted academic practice. No use, distribution or reproduction is permitted which does not comply with these terms. 